\title{
The properties of the mixture of beef tallow and rapeseed oil with a high content of tallow after chemical and enzymatic interesterification
}

\author{
By Boleslaw Kowalski, Katarzyna Tarnowska and Eliza Gruczynska
}

\author{
Agricultural University (SGGW), Department of Food Technology, 159C Nowoursynowska, \\ 02-787 Warsaw, Poland, e-mail: kowalski@delta.sggw.waw.pl
}

\section{RESUMEN}

Propiedades de la mezcla de sebo y aceite de colza con alto contenido en sebo después de la interesterificación química y enzimática.

Una mezcla de sebo con aceite de colza $(3: 1 \mathrm{p} / \mathrm{p})$ fue interesterificada usando metóxido de sodio y lipasas inmovilizadas de Rhizomucor miehei (Lipozyme IM) and Candida antarctica (Novozym 435) como catalizadores. La interesterificación química se llevó a cabo a $60^{\circ} \mathrm{C}$ y $90^{\circ} \mathrm{C}$ durante 0,5 y $1,5 \mathrm{~h}$ usando $0,4,0,6$ y $1,0 \mathrm{p}-\%$ de $\mathrm{CH}_{3} \mathrm{ONa}$. Dependiendo del catalizador usado en la interesterificación enzimática se llevaron a cabo las experiencias a $60^{\circ} \mathrm{C}$ durante $8 \mathrm{~h}$ (Lipozyme IM) y a $80^{\circ} \mathrm{C}$ durante $4 \mathrm{~h}$ (Novozym 435). Las dosis del catalizador se mantuvieron constantes $(8 \%)$ pero el contenido en agua varió del $2 \%$ al $10 \%$. La mezcla inicial y los productos de interesterificación se separaron mediante columna cromatográfica en una fracción que contenía los triglicéridos, y otra, carente de triglicéridos, que contenía ácidos grasos libres, mono- y di-glicéridos. Se ha determinado que las concentraciones de ácidos grasos libres y glicéridos parciales se incrementa durante la interesterificación. Los puntos de deslizamiento y los contenidos de grasa sólida, de la fracción de triglicéridos de las grasas interesterificadas, fueron menores cuando se compararon con las mezclas no esterificadas. También se han determinado las distribuciones sn-2 y sn-1,3 de los ácidos grasos de las fracciones de triglicéridos antes y después de la interesterificación. Estas distribuciones fueron "al azar" después de la interestrificación química y "cuasi al azar" cuando se usó Novozym 435. La composición de ácidos grasos en la posición sn-2 se mantuvo prácticamente constante, comparada con la mezcla inicial, cuando se uso Lipozyme IM. Las grasas interesterificadas y la fracción triglicerídica mostraron una estabilidad oxidativa menor, de acuerdo con los tiempos de inducción determinados mediante Rancimat. La adición de $0,02 \%$ de BHA o BHT a las grasas interesterificadas mejoró la estabilidad.

PALABRAS-CLAVE: Aceite de colza - Interesterificación enzimática - Interesterificación química - Lipasa - Sebo.

\section{SUMMARY}

The properties of the mixture of beef tallow and rapeseed oil with a high content of tallow after chemical and enzymatic interesterification.

A mixture of beef tallow with rapeseed oil ( $3: 1 \mathrm{wt} / \mathrm{wt})$ was interesterified using sodium metoxide or immobilized lipases from Rhizomucor miehei (Lipozyme IM) and Candida antarctica (Novozym 435) as catalysts. Chemical interesterifications were carried out at 60 and $90{ }^{\circ} \mathrm{C}$ for 0.5 and $1.5 \mathrm{~h}$ using $0.4,0.6$ and 1.0 wt- $\% \mathrm{CH}_{3} \mathrm{ONa}$. Depending on the catalyst used enzymatic interesterifications were carried out at $60^{\circ} \mathrm{C}$ for $8 \mathrm{~h}$ (Lipozyme IM) or at $80^{\circ} \mathrm{C}$ for $4 \mathrm{~h}$ (Novozym 435 ). The catalysts doses were kept constant (8\%) but the water content in catalysts varied from 2 to $10 \%$. The starting mixture and the interesterified products were separated by column chromatography into a pure triacylglycerol fraction and a non-triacylglycerol fraction, which contained free fatty acids, mono- and diacylglycerols. It was found that the concentrations of free fatty acids and partial acylglycerols increased after interesterification. The slip melting points and solid fat contents of the triacylglycerol fractions isolated from interesterified fats were lower when compared with nonesterified blends. The sn-2 and sn-1,3 distributions of fatty acids in the triacylglycerol fractions before and after interesterification were determined.These distributions were random after chemical interesterification and near random when Novozym 435 was used. When Lipozyme IM was used, the fatty acid composition at the sn-2 position remained practically unchanged compared with the starting blend. The interesterified fats and isolated triacylglycerols had reduced oxidative stability, as assessed by Rancimat induction times. The addition of $0.02 \%$ of $\mathrm{BHA}$ or $\mathrm{BHT}$ to the interesterified fats improved their stabilities.

KEY-WORDS: Beef tallow - Chemical interesterification Enzymatic interesterification - Lipase - Rapeseed oil.

\section{INTRODUCTION}

The annual European production of beef tallow is about 1.42 million tonnes (Gunstone, 2000) with the annual production in Poland being about 0.12 million tons. Because of its high melting point and low level of polyunsaturated fatty acids, beef tallow is considered a less valuable fat not suitable for direct human consumption. Although minor quantities of beef tallow are used for edible purposes such as frying fats or shortenings, tallow should be modified before use. One of the possible ways of tallow modification is its interesterification with vegetable oils. The selection of vegetable oil depends on regional production. In Poland only rapeseed oil can be taken into account, as its annual production is about 0.35 million tons (Gunstone, 2001).

There are several published papers dealing with interesterification of beef tallow with vegetable oils. Chobanov and Chobanova (1977) performed chemical interesterifications of tallow or lard with sunflower oil in their studies on alteration of triacylglycerols due to randomization of fatty acids. Because practically no new trans fatty acids are formed during interesterification, it was used as an alternative to hydrogenation for the production of plastic fats for use as margarine oils and the results for tallow + soybean oil blends were reported ( Lo and Handel , 1983). Interesterification, chemical or enzymatic, can be a means of altering either the 
physical and nutritional properties. Rodriguez et al. (2001) studied the interesterification of tallow and sunflower oil mixtures. They have found that interesterification resulted in an appropriate method to improve the physical properties of tallow, whereas blending did not significantly modify it. Recently the results of the studies on the chemical interesterification of rapeseed oil + tallow blends performed with and without hydrocarbon solvent were reported (Gruczynska et al., 2002, Kowalski et al., 2004 a). It appears that the presence of solvent influenced the melting properties, solid fat contents and fatty acid distribution of the triacylglycerols separated from the mixtures after interesterification. Interesterifications of tallow + sunflower, or tallow + rapeseed oil blends catalyzed by immobilized sn-1, 3 specific lipases were described (Foglia et al., 1993, Forsell et al., 1992). The interesterified blends displayed a reduction in the melting point temperature and in the solid fat contents compared with blends before interesterification.

Ledochowska and Wilczynska (1998) interesterified a tallow: rapeseed oil (2:3, wt/wt) mixture. The aim of their study was a comparison of the oxidative stability of the product before and after chemical and enzymatic (sn-1, 3 specific lipase) interesterification. They found that interesterification reduced the resistance of products to thermal oxidation. The highest degree of this reduction was observed for crude products after enzymatic and for separated triacylglycerols after chemical interesterifications. Bhattacharyya et al. (2000) have carried out the studies with an intention to prepare shortenings, margarine fat bases, cocoabutter substitutes and vanaspati substitute from tallow. After fractionation of tallow from acetone the stearine and oleine fractions obtained were blended and interesterified with various liquid oils using $\mathrm{CH}_{3} \mathrm{ONa}$ or an immobilized lipase from Rhizomucor miehei. As indicated from their slip melting points and solid fat indexes, the products thus prepared were found to be suitable for their intended applications.

The purpose of this paper was to investigate the selected chemical and physical properties of the beef tallow and rapeseed oil blend modified by interesterification. Both chemical and enzymatic interesterifications were studied and the properties of the final fats were compared with those of the starting blend. The components of this blend are readily available, and there is a need to utilize beef tallow so therefore the interesterification of beef tallow and rapeseed oil blends could be reduced to normal practice.

\section{MATERIALS AND METHODS}

\subsection{Materials}

The rapeseed oil (RSO) was commercially refined, bleached and deodorized. Edible beef tallow
(T) was obtained from a local market and refined and bleached in our laboratory. The mixture $75 \% \mathrm{~T}+25 \%$ RSO was prepared by weight. Its properties were as follows: acid value $=1.5 \mathrm{mg} \mathrm{KOH} / \mathrm{g}$, triacylglycerol content $=97.0 \%$, mono- and diacylglycerol content $=2.4 \%$, slip melting point $=39.9^{\circ} \mathrm{C}$. The temperature dependence of solid fat content for the mixture is illustrated in Figures 1 and 2. The Rancimat induction time measured at $120^{\circ} \mathrm{C}$ for the initial blend was 30.2 $\pm 0.2 \mathrm{~h}$. The main fatty acid composition and their distribution among sn-2 and sn-1, 3 positions of triacylglycerols in mixture are listed in Table 1.
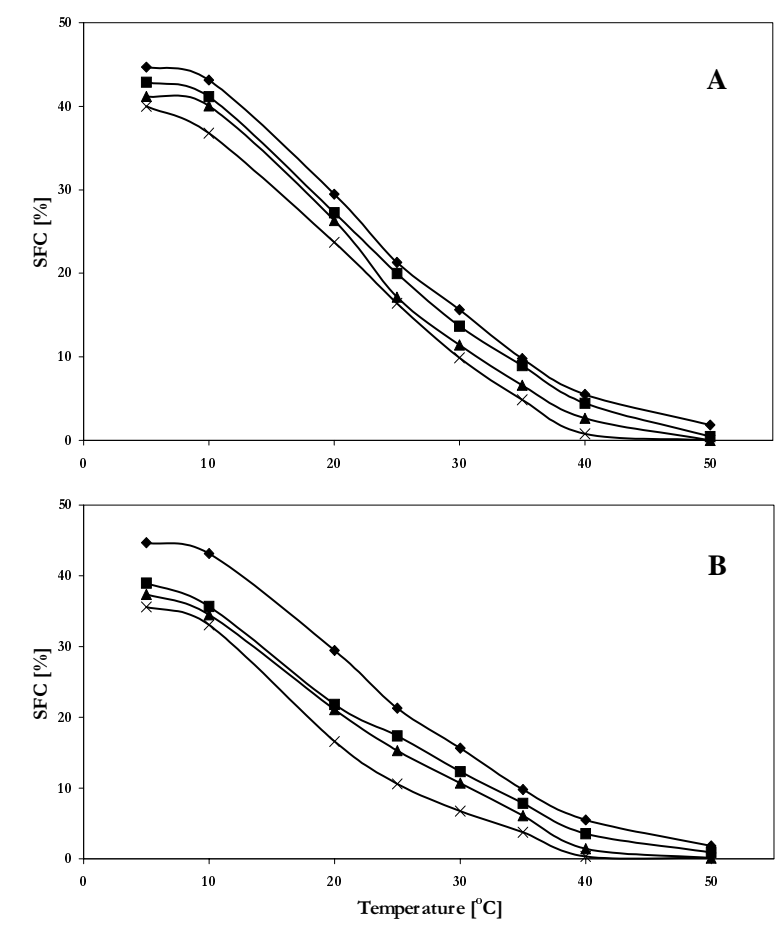

$\rightarrow$ Before transesterification, tensesterified with sodium methoxide content: $-0.4 \% \rightarrow 0.6 \% * 1.0 \%$

Figure 1

The solid fat content versus temperature for initial $T: R S O$

(3:1, wt/wt) mixture and for TAG fractions isolated after chemical interesterifications at $90{ }^{\circ} \mathrm{C}$ for $0.5 \mathrm{~h}(\mathrm{~A})$ and $1.5 \mathrm{~h}(\mathrm{~B})$.

\subsection{Catalysts}

Chemical interesterifications were catalyzed by powdered sodium metoxide $\left(\mathrm{CH}_{3} \mathrm{ONa}\right.$, Merck, Germany) and it was used as supplied. As catalysts for enzymatic interesterification two commercial preparations Lipozyme IM and Novozym 435 (Novozymes A/S, Bagsvaerd, Denmark) were used. Lipozyme IM contains immobilized lipase from Rhizomucor miehei and Novozym 435 contains immobilized lipase from Candida antarctica. Commercial Lipozyme IM and Novozym 435 contained $4 \%$ and $2 \%$ of water, respectively. 

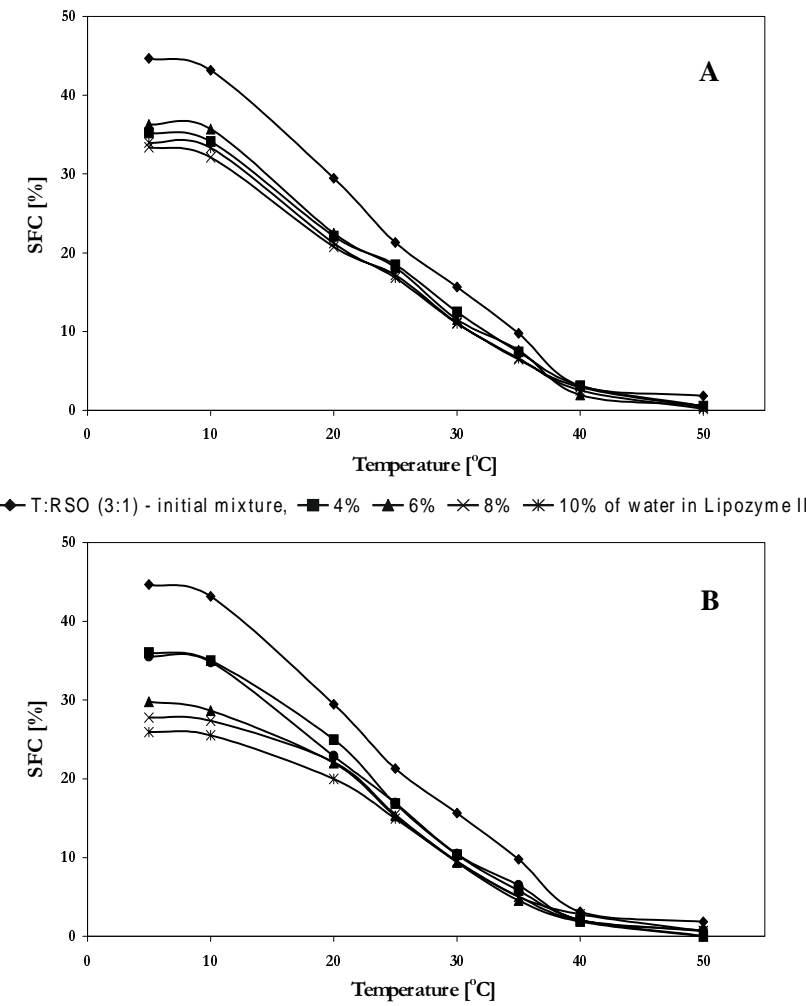

$\rightarrow$ T:RSO $(3: 1)$ - initial mixture, $\rightarrow 2 \% \rightarrow 4 \% \rightarrow 6 \% \rightarrow 8 \% \rightarrow-10 \%$ of water in Novozym 435

Figure 2

The solid fat content versus temperature for initial $\mathrm{T}: \mathrm{RSO}(3: 1, \mathrm{wt} / \mathrm{wt})$ mixture and for TAG isolated after enzymatic interesterifications catalyzed by Lipozyme IM (A) and by Novozym 435 (B) containing different amounts of water.

\subsection{Chemicals and solvents}

All chemicals and solvents used in this study were reagent grade and their producers are mentioned throughout the paper.

\subsection{Chemical interesterifications}

Immediately prior to interesterification fats were dried at $90{ }^{\circ} \mathrm{C}$ under reduced pressure. Flasks containing fat blends were flushed with nitrogen, stoppered and positioned in a thermostated mineral-oil bath shaker. After thermal equilibration of samples at 60 or $90^{\circ} \mathrm{C}$ the catalyst $(0.4,0.6$ or $1.0 \%$ $\mathrm{CH}_{3} \mathrm{ONa}$ ) was added under nitrogen. The interesterification was carried out with continuous shaking for 0.5 or 1.5 hours. The reaction was stopped by the addition of hot water containing $5 \%$ $\mathrm{H}_{3} \mathrm{PO}_{4}$. Interesterified fats were extracted with hexane, washed with water and dried. Hexane was evaporated under reduced pressure and remaining interesterified fats were analyzed.

\subsection{Enzymatic interesterifications}

Flasks containing fats were prepared as for chemical interesterification and positioned in thermostated mineral-oil bath shaker. After thermal equilibration $\left(80^{\circ} \mathrm{C}\right.$ for Novozym 435 or $60{ }^{\circ} \mathrm{C}$ for Lipozyme IM) $8 \%$ of enzymatic catalyst was added. Water content in biocatalysts $(2 \%, 4 \%, 6 \%, 8 \%$, or $10 \%)$ was adjusted directly before reaction. The interesterifications were performed with continuous shaking. After a

Table 1

Fatty acids composition and distribution between the sn-2 and sn-1, 3 positions for triacylglycerols of a mixture of tallow (75\%) and rapeseed oil $(25 \%)$

\begin{tabular}{lcccc}
\hline Fatty acid & $\begin{array}{c}\text { Fatty acids } \\
\text { composition } \\
\text { of TAG } \\
\text { [\%] }\end{array}$ & $\begin{array}{c}\text { Fatty acids composition [\%] } \\
\text { in positions: }\end{array}$ & $\begin{array}{c}\text { Percentage of } \\
\text { a given fatty } \\
\text { acid } \\
\text { in sn-2 } \\
\text { position }\end{array}$ \\
\cline { 3 - 4 } $14: 0$ & 2.9 & 5.5 & 1.6 & 63.2 \\
$16: 0$ & 23.0 & 15.8 & 26.6 & 22.9 \\
$16: 1$ (9-cis) & 3.5 & 3.6 & 3.7 & 32.7 \\
$18: 0$ & 11.6 & 6.4 & 14.2 & 18.4 \\
$18: 1$ (9-cis) & 40.5 & 42.9 & 39.5 & 35.2 \\
$18: 2(9,12-c i s)$ & 6.1 & 8.8 & 4.7 & 48.3 \\
$18: 3$ (9, 12, 15-cis) & 2.5 & 4.0 & 1.9 & 51.3 \\
$20: 0$ & 0.5 & 0.3 & 0.6 & 20.6 \\
$20: 1$ (9-cis) & 0.7 & 0.4 & 0.8 & 20.0 \\
$22: 1$ (13-cis) & 0.2 & - & 0.3 & - \\
\hline
\end{tabular}


predetermined time (Novozym 4 h, Lipozyme 8 h) interesterification was stopped by filtering off the biocatalyst.

\subsection{Determination of free fatty acids}

Free fatty acids (FFA) were determined by titration of the fat sample dissolved in the mixture of ethanol: diethyl ether $(1: 1 \mathrm{vol} / \mathrm{vol})$ with $0.1 \mathrm{M}$ ethanol potassium hydroxide solution. The mean molar mass $(274 \mathrm{~g} / \mathrm{mole})$ of fatty acids from analyzed samples was calculated based on the results of gas-liquid chromatography analyses.

\subsection{Gas-liquid chromatography analyses}

The fatty acid composition of the fats studied was determined by gas-liquid chromatography (GLC) after conversion of the fats to fatty acid methyl esters. The apparatus and procedure are reported elsewhere (Kowalski et al., 2000).

\subsection{Separation of fat samples into triacylglycerol and non-triacylglycerol fractions}

Fats before and after interesterification were separated into triacylglycerols and non-TAG fraction, refered to as polar fraction (PF), by column chromatography on silica gel (SG 60, 70-230 mesh, Merck, Germany). The TAG were eluted with the mixture of petroleum ether : diethyl ether $=87: 13 \mathrm{vol} / \mathrm{vol}$ and the PF fraction containing FFA, monoacylglycerols (MAG) and diacylglycerols (DAG) was eluted with diethyl ether. The weight percentages of TAG and PF were determined after evaporation of the eluting solvent.(Polish Standard PN-ISO 8420, 1995).

\subsection{Slip melting point}

The slip melting point, (SMP, $\left.{ }^{\circ} \mathrm{C}\right)$ the temperature at which the fat confined in open capillary immersed in water moves upward was determined in accordance with Polish Standard PN-ISO 638, 1991.

\subsection{Solid fat content by $\mathrm{nmr}$ analysis}

The solid fat content (SFC, \%) of TAG as a function of temperature $\left(5-50{ }^{\circ} \mathrm{C}\right)$ was determined by a pulse nuclear magnetic resonance in a Brucker Minispec 120 NMR Analyzer. Samples for SFC determinations were prepared according to the Polish Standard PN-ISO 8292, 1991.

\subsection{Oxidative stability by Rancimat measurements}

The induction times for oxidation ( $\tau_{\text {Rancimat }}$ ) of fats studied were measured using Methrom Rancimat apparatus model 679 (Herisau, Switzerland). The tests were carried out at $120^{\circ} \mathrm{C}$ in triplicate, with 2.5 $\pm 0.2 \mathrm{~g}$ of fat. Air flow rates were set at $20 \mathrm{dm}^{3} / \mathrm{h}$. Details of determinations were reported elsewhere (Kowalski et al., 2004 b). Reported with precision of one tenth of an hour the $\tau$ Rancimat values are the average of three determinations.

\subsection{Positional distribution of fatty acids among sn-2 and sn-1,3 positions of TAG}

The positional distribution of fatty acids between sn-2 and sn- 1 and 3 positions of triacylglycerols were determined using the method developed by Brockerhoff (1965). The method is based on the ability of an enzyme pancreatic lipase to selectively hydrolyze ester bonds in the sn-1, 3 positions of TAG. The products of lipolysis were separated by thin layer chromatography (TLC) on plates covered with Kieselgel G (Merck, Germany) with the developing system petroleum ether : diethyl ether : acetic acid = $70: 30: 1 \mathrm{vol} / \mathrm{vol} / \mathrm{vol}$. The sn-2 MAG band was scraped off and its lipids were extracted into diethyl ether and subsequently used for fatty acid analysis by GLC. Next, the composition of fatty acids in the sn-1, 3 positions of TAG was computed from the GLC results obtained for samples before and after enzymatic hydrolysis with pancreatic lipase.

\section{RESULTS AND DISCUSSION}

The chemical interesterifications of beef tallow and rapeseed oil blends containing $75 \%$ of tallow were performed at various temperatures, times and $\mathrm{CH}_{3} \mathrm{ONa}$ concentrations as specified in Table 2 . During interesterification of the initial mixture apart from desirable triacylglycerols free fatty acids, monoand diacylglycerols were also formed. They were determined and the results are listed in Table 2. The FFA and MAG + DAG contents in interesterified samples increased when compared with the starting blend and these increases were proportional to the temperature and time of reaction and to the catalyst concentration. Consequently the contents of TAGs in post-reaction mixtures decreased and there is inversion proportionality against time, temperature and catalyst concentration.

Ledochowska and Wilczynska (1998) in their study on interesterification of tallow + rapeseed oil blend $(6: 4, w / w)$ have observed similar trends. The MAG concentrations in the MAG + DAG fractions was generally low. Our preliminary determinations gave values close to zero when the concentration of $\mathrm{CH}_{3} \mathrm{ONa}$ used was 0.6 or $1.0 \%$. The relatively large contents of DAG in the interesterification products are presumably caused by the reaction of MAG with FFA and by the high amount of catalyst used. During the initial step of reaction sodium diacylglycerol 
Table 2

Free fatty acids (FFA), mono- and diacylglycerol (MAG + DAG) and triacyl glycerol (TAG) contents for products of chemical interesterifications of a mixture of tallow $(75 \%)$ and rapeseed oil $(25 \%)$, and slip melting points (SMP) of triacylglycerols

\begin{tabular}{|c|c|c|c|c|c|c|c|c|c|}
\hline \multirow{2}{*}{$\begin{array}{c}\text { Interesterification } \\
\text { Temperature } \\
{\left[{ }^{\circ} \mathrm{C}\right]}\end{array}$} & \multirow{2}{*}{$\begin{array}{c}\text { Catalyst } \\
\left(\mathrm{CH}_{3} \mathrm{ONa}\right) \\
{[\%]}\end{array}$} & \multicolumn{4}{|c|}{ Interesterification time $=0.5 \mathrm{~h}$} & \multicolumn{4}{|c|}{ Interesterification time $=1.5 \mathrm{~h}$} \\
\hline & & $\begin{array}{c}\text { FFA } \\
{[\%]}\end{array}$ & $\begin{array}{c}\text { MAG+ } \\
\text { DAG } \\
{[\%]}\end{array}$ & $\begin{array}{c}\text { TAG } \\
{[\%]}\end{array}$ & $\begin{array}{c}\text { SMP } \\
\text { of TAG } \\
{\left[{ }^{\circ} \mathrm{C}\right]}\end{array}$ & $\begin{array}{c}\text { FFA } \\
{[\%]}\end{array}$ & $\begin{array}{c}\text { MAG+ } \\
\text { DAG } \\
{[\%]}\end{array}$ & $\begin{array}{c}\text { TAG } \\
{[\%]}\end{array}$ & $\begin{array}{c}\text { SMP } \\
\text { of TAG } \\
{\left[{ }^{\circ} \mathrm{C}\right]}\end{array}$ \\
\hline 60 & 0.4 & 1.1 & 4.0 & 94.9 & 32.9 & 1.3 & 6.1 & 92.6 & 32.8 \\
\hline 60 & 0.6 & 1.6 & 5.0 & 93.4 & 30.7 & 1.8 & 7.4 & 90.8 & 30.0 \\
\hline 60 & 1.0 & 2.6 & 7.9 & 89.5 & 28.8 & 3.1 & 10.3 & 86.6 & 26.9 \\
\hline 90 & 0.4 & 1.2 & 5.3 & 93.5 & 37.8 & 1.4 & 6.3 & 92.3 & 37.2 \\
\hline 90 & 0.6 & 1.8 & 6.6 & 91.6 & 36.0 & 2.0 & 6.7 & 91.3 & 35.6 \\
\hline 90 & 1.0 & 2.9 & 10.0 & 87.1 & 33.0 & 3.2 & 11.8 & 85.0 & 30.8 \\
\hline
\end{tabular}

(active form of catalyst) is formed. After interesterification the catalyst is decomposed by water, the soluble by products are removed in the water phase and DAG are formed. The Rancimat tests for crude products of chemically interesterified blends showed that the $\tau_{\text {Rancimat }}$ times were drastically reduced $(4.5 \pm 0.1 \mathrm{~h})$ compared with $30.2 \pm 0.2 \mathrm{~h}$ for the starting mixture. From post-reaction mixtures the TAG fractions were isolated by column chromatography and the Rancimat tests for them were also performed. The $\tau_{\text {Rancimat }}$ values obtained for TAG were in the range of $0.5 \pm 0.1 \mathrm{~h}$ independent of temperature, time and $\mathrm{CH}_{3} \mathrm{ONa}$ concentration during interesterifications of starting fat. When TAG were inhibited with $0.02 \%$ of BHA or $0.02 \%$ of BHT their $\tau_{\text {Rancimat }}$ values increased to $8.6 \pm 0.2 \mathrm{~h}$ and $6.2 \pm 0.2$ $h$, respectively.

As seen in Table 2 the SMP values for TAG of interesterified blends are lower $\left(37.8-30.0^{\circ} \mathrm{C}\right)$ than for the starting blend $\left(39.9^{\circ} \mathrm{C}\right)$. When time and catalyst concentrations during interesterifications increased the SMP values of TAGs decreased, although the effect of the reaction temperature on the SMP was not critical. The dependencies of solid fat contents against temperature for TAG fractions were determined by pulse-NMR and the results are illustrated in Figure 1. As seen in Figure 1 the SFC values for TAGs from interesterified blends are lower than for the initial blend. The influences of time and temperature of interesterification and the concentrations of $\mathrm{CH}_{3} \mathrm{ONa}$ used on the SFC values of TAGs were similar as for SMP values. Both SMP and SFC results confirmed the "extra softening" of interesterified products compared with the starting blend. As expected, the positional distribution of fatty acids among sn-2 and sn-1,3 in TAG of chemically interesterified blends was near random, as shown in Table 3.

For enzymatic interesterifications, the blends studied the time and temperature of reaction and enzymatic catalysts doses were established in our earlier experiments, and these parameters were kept constant as specified in the Materials and Methods section. Only the water content in the catalysts used was adjusted in the range of $2-10 \%$ as listed in Table 4. The crude post-reaction mixtures were characterized by determinations of FFA, MAG + DAG and TAG percentages and they are listed in Table 4. The amounts of these fractions in the interesterified samples strongly depend on the water content in the system. It was found that the higher the amount of water in the reaction system, the higher the FFA and MAG + DAG contents and the smaller the TAG content. Such conclusion is in agreement with the findings of other authors (Foglia et al., 1993, Forssell et al., 1992, Ledochowska and Wilczynska, 1998) studying the enzymatic interesterification of tallow + vegetable oil systems. There are reports (Ledochowska and Wilczynska, 1998, Ledochowska and Datta, 1998, Mohamed et al., 1993) that the percentage of MAG in enzymatically interesterified fats is low $(\sim 1 \%)$ because MAG are reactive and rapidly undergo esterification. In our experiments it appeared that during interesterifications catalyzed by Novozym 435 more FFA and MAG + DAG and less TAG were formed than when equally moistured 
Table 3

Fatty acids composition and distribution between the sn-2 and sn-1,3 positions for triacylglycerols isolated from products of chemical interesterification $\left(90^{\circ} \mathrm{C}, 1.5 \mathrm{~h}, \mathrm{CH}_{3} \mathrm{ONa}\right.$ content $1.0 \%$ ) of a mixture of tallow (75\%) and rapeseed oil (25\%)

\begin{tabular}{lcccc}
\hline Fatty acid & $\begin{array}{c}\text { Fatty acids } \\
\text { composition } \\
\text { of TAG } \\
\text { [\%] }\end{array}$ & \multicolumn{2}{c}{$\begin{array}{c}\text { [\%] of fatty acids } \\
\text { in positions: }\end{array}$} & $\begin{array}{c}\text { Percentage of } \\
\text { a given fatty } \\
\text { acid } \\
\text { in sn-2 } \\
\text { position }\end{array}$ \\
\cline { 3 - 4 } 14:0 & 2.8 & 3.0 & 2.7 & 35.7 \\
$16: 0$ & 23.0 & 23.0 & 23.0 & 33.3 \\
$16: 1$ (9-cis) & 3.5 & 3.7 & 3.4 & 35.2 \\
$18: 0$ & 11.6 & 11.6 & 11.6 & 33.3 \\
$18: 1$ (9-cis) & 40.4 & 40.8 & 40.2 & 33.7 \\
$18: 2(9,12-$-cis $)$ & 5.9 & 5.9 & 5.9 & 33.3 \\
$18: 3$ (9, 12, 15-cis) & 2.4 & 2.5 & 2.4 & 34.2 \\
$20: 0$ & 0.5 & 0.5 & 0.5 & 33.3 \\
$20: 1$ (9-cis) & 0.8 & 0.7 & 0.8 & 30.4 \\
$22: 1$ (13-cis) & 0.2 & 0.2 & 0.2 & 33.3 \\
\hline
\end{tabular}

Lipozyme IM was used. The differences in the yields of these fractions were especially distinct when the catalysts contained $10 \mathrm{w} \%$ water.

The crude products after enzymatic interesterifications showed Rancimat induction times of $5.2 \pm 0.2 \mathrm{~h}$ or 3.5 $\pm 0.2 \mathrm{~h}$ when commercial Nowozym 435 or commercial Lipozyme IM was used for interesterifications, respectively. From crude interesterified fats the TAG fractions were isolated and their Rancimat induction times were measured. The $\tau_{\text {Rancimat }}$ values for interesterified, in the presence of Novozym 435, TAGs were $1.9 \pm 0.1 \mathrm{~h}$. When Lipozyme IM was used the $\tau_{\text {Rancimat }}$ values were $0.5 \pm 0.1 \mathrm{~h}$. The TAG fractions inhibited with $0.02 \%$ of BHA showed $\tau_{\text {Rancimat }}=7.4 \pm$ $0.1 \mathrm{~h}$ (Novozym 435) or $4.8 \pm 0.1 \mathrm{~h}$ (Lipozyme IM). When $0.02 \%$ BHT was used for inhibition the measured $\tau_{\text {Rancimat }}$ values were $6.2 \pm 0.1 \mathrm{~h}$ (Novozym 435) and $2.6 \pm 0.1 \mathrm{~h}$ (Lipozyme IM).

The slip melting point for TAG fractions was also measured and the results are listed in Table 4. As seen in Table 4 the SMPs of interesterified TAG are lower than for the starting blend. The reductions of SMPs were proportional to the water content in enzymatic catalyst used for interesterification. It appears that Novozym 435 was more active in SMP reduction $(4-10 \%)$ than Lipozyme IM with SMP reductions of $(1-3 \%)$. The reduction of SMP of interesterified tallow + rapeseed oil blend is caused by an (or the) alteration of lipid structure on the (or a) molecular level. Due to an (or the) exchange of fatty acids within and between new TAG acylglycerols are formed and new interrelations among them can appear. The distributions of fatty acids between sn-2 and sn-1,3 positions of TAGs after enzymatic interesterifications were determined for selected systems. The results are listed in Tables 5 and 6 . When as the catalyst

Novozym 435 was used the comparison of the data listed in Tables 1 and 5 suggests that some positional randomization of fatty acids in TAG after interesterification has occurred. On the other hand, the sn-2 percentage data (Table 5) showed that although there is some degree of randomization, the distribution of fatty acids we have observed is still far from statistical (33.3\%).

A different situation was observed for TAG obtained from the enzymatic interesterification catalyzed by Lipozyme IM. Due to the positional $(s n-1,3)$ specificity of this lipase the interesterification in this case occurred mainly in external positions of TAG. Comparison of the data in Tables 1 and 6 indicated that the distributions of fatty acids at the sn-2 and sn-1,3 positions in the TAG of the initial mixture and of the final interesterification product are similar. As the enzyme reacts on sn-1,3 ester linkages, the percentages of particular fatty acids in 
Table 4

Free fatty acid (FFA), mono- and diacylglycerol (MAG + DAG) and triacylglycerol (TAG) contents for products of enzymatic interesterification of a mixture of tallow $(75 \%)$ and rapeseed oil $(25 \%)$, and slip melting points (SMP) of triacylglycerols

\begin{tabular}{|c|c|c|c|c|c|}
\hline \multirow{2}{*}{ Catalyst } & \multirow{2}{*}{$\begin{array}{c}\text { Water } \\
\text { content in } \\
\text { catalyst [\%] }\end{array}$} & \multicolumn{3}{|c|}{$\begin{array}{l}\text { Percentage content } \\
\text { of }\end{array}$} & \multirow{2}{*}{$\begin{array}{c}\text { SMP } \\
\text { of TAG } \\
{\left[{ }^{\circ} \mathrm{C}\right]}\end{array}$} \\
\hline & & FFA & MAG + DAG & TAG & \\
\hline \multirow{5}{*}{ 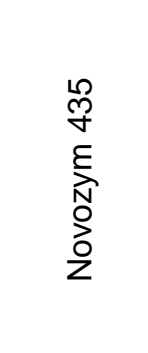 } & 2 & 2.3 & 6.2 & 91.5 & 38.4 \\
\hline & 4 & 4.1 & 9.3 & 86.6 & 37.9 \\
\hline & 6 & 5.3 & 10.8 & 83.9 & 37.2 \\
\hline & 8 & 6.5 & 12.1 & 81.4 & 36.1 \\
\hline & 10 & 7.3 & 21.2 & 71.5 & 35.9 \\
\hline \multirow{4}{*}{ 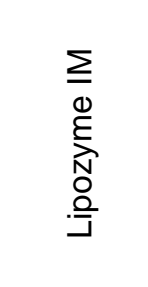 } & 4 & 3.9 & 5.9 & 90.2 & 39.4 \\
\hline & 6 & 4.5 & 9.1 & 86.4 & 39.2 \\
\hline & 8 & 5.4 & 10.9 & 83.7 & 39.0 \\
\hline & 10 & 6.8 & 13.7 & 79.5 & 38.8 \\
\hline
\end{tabular}

Table 5

Fatty acids composition and distribution among the sn-2 and sn-1, 3 positions for triacylglycerols obtained from the enzymatic interesterification $\left(8 \%\right.$ Novozym $\left.435,80^{\circ} \mathrm{C}, 4 \mathrm{~h}\right)$ of a mixture of tallow $(75 \%)$ and rapeseed oil $(25 \%)$

\begin{tabular}{lcccc}
\hline Fatty acid & $\begin{array}{c}\text { Fatty acids } \\
\text { composition } \\
\text { of TAG } \\
\text { [\%] }\end{array}$ & $\begin{array}{c}\text { Fatty acids composition [\%] } \\
\text { in positions: }\end{array}$ & $\begin{array}{c}\text { Percentage of } \\
\text { a given fatty } \\
\text { acid } \\
\text { in sn-2 } \\
\text { position }\end{array}$ \\
\cline { 3 - 4 } $14: 0$ & 2.4 & $\mathbf{s n - 2}$ & $\mathbf{s n - 1 , 3}$ & 38.9 \\
$16: 0$ & 22.7 & 22.8 & 2.2 & 33.4 \\
$16: 1$ (9-cis) & 2.2 & 2.3 & 2.2 & 34.3 \\
$18: 0$ & 17.7 & 17.4 & 17.8 & 32.8 \\
$18: 1$ (9-cis) & 40.4 & 40.6 & 40.3 & 33.5 \\
$18: 2$ (9, 12-cis) & 5.2 & 5.7 & 5.0 & 36.5 \\
$18: 3$ (9, 12, 15-cis) & 2.2 & 2.5 & 2.1 & 37.9 \\
$20: 0$ & 0.3 & 0.3 & 0.3 & 33.3 \\
$20: 1$ (9-cis) & 0.6 & 0.6 & 0.6 & 30.3 \\
$22: 1$ (13-cis) & 0.3 & 0.2 & 0.4 & 22.2 \\
\hline
\end{tabular}


Table 6

Fatty acid composition and distribution between the sn-2 and sn-1, 3 positions for triacylglycerols obtained from the enzymatic interesterification ( $8 \%$ Lipozyme IM, $60^{\circ} \mathrm{C}, 8 \mathrm{~h}$ ) of a mixture of tallow $(75 \%)$ and rapeseed oil (25\%)

\begin{tabular}{lcccc}
\hline Fatty acid & $\begin{array}{c}\text { Fatty acids } \\
\text { composition } \\
\text { of TAG } \\
\text { [\%] }\end{array}$ & $\begin{array}{c}\text { Fatty acids composition [\%] } \\
\text { in positions: }\end{array}$ & $\begin{array}{c}\text { Percentage of } \\
\text { a given fatty } \\
\text { acid } \\
\text { in sn-2 } \\
\text { position }\end{array}$ \\
\cline { 3 - 4 } 14:0 & 2.5 & 5.0 & 1.2 & 67.6 \\
$16: 0$ & 22.7 & 17.2 & 25.4 & 25.3 \\
$16: 1$ (9-cis) & 2.2 & 2.4 & 2.1 & 36.4 \\
$18: 0$ & 17.6 & 9.8 & 21.5 & 18.5 \\
$18: 1$ (9-cis) & 40.3 & 42.7 & 39.1 & 35.3 \\
$18: 2(9,12-c i s)$ & 5.2 & 7.6 & 4.0 & 48.7 \\
18:3 (9, 12, 15-cis) & 2.2 & 3.8 & 1.4 & 57.6 \\
$20: 0$ & 0.3 & 0.3 & 0.3 & 33.3 \\
$20: 1$ (9-cis) & 0.6 & 0.4 & 0.7 & $22, .2$ \\
$22: 1$ (13-cis) & 0.2 & - & 0.3 & - \\
\hline
\end{tabular}

sn-2 positions of TAG in comparison with their counterparts, in the initial blend remain nearly unchanged. The small changes in fatty acids in sn-2 position may result from acyl migration in the TAG species during a prolonged interesterification time, as reported by Xu et al. (1998).

The altered triacylglycerol composition of the interesterified tallow - rapeseed oil mixture was also reflected in the solid fat content over the temperature range of 5 to $50{ }^{\circ} \mathrm{C}$. Reductions in the solid fat content were detected for the TAG fractions isolated from blends after interesterification. The experimental data of SFC dependency versus temperature for the initial blend and enzymatically interesterified TAG are shown in Figure 2. The highest reduction in SFC was observed for TAG isolated from mixtures interesterified using Novozym 435 that contained $10 \%$ water.

Tallow used for blending contained $1.4 \%$ of $\mathrm{C}_{18: 1}$, trans, and rapeseed oil contained $0.1 \% \mathrm{C}_{18: 2 \text {,trans }}$ and $0.8 \% \mathrm{C}_{18: 3, \text { trans }}$ fatty acids. After blending the determined concentrations of trans isomers of fatty acids with 1 and with 3 double bonds were $0.4 \%$ and $0.2 \%$, respectively and they remained on the same levels after interesterifications.

The results obtained in this work have shown that interesterifications of T + RSO blend containing $75 \%$ of tallow produce new fats which do not have natural equivalents. These fats after deacidification can be fitted for various applications involving wider utilization of beef tallow.

\section{REFERENCES}

Bhattacharyya S., Bhattacharyya DK., De BK. 2000. Modification of tallow fractions in the preparation of edible fat products. Eur. J. Lipid Sci. Technol. 102, 323-328.

Brockerhoff H. 1965. A stereospecific analysis of triglycerides. J. Lipid Research 6, 10-15.

Chobanov DR., Chobanova R. 1977. Alterations in glyceride composition during interesterification of mixtures of sunflower oil with lard and tallow. J. Am. Oil Chem. Soc. 54, 47-49.

Foglia TA., Petruso K., Feairheller SH. 1993. Enzymatic interesterification of tallow-sunflower oil mixtures. $J$. Am. Oil Chem. Soc. 70, 281-285.

Forssell P., Kervinen R., Lappi M., Linko P., Suortti T., Poutanen K. 1992. Effect of enzymatic interesterification on the melting point of tallow rapeseed oil (LEAR) mixture. J. Am. Oil Chem. Soc. 69, 126-129.

Gruczynska E., Kowalski B., Tarnowska K., Dziurosz J., Kowalska M., Bekas W. 2002. Modification of beef tallow and its mixtures with rapeseed oil by chemical interesterification. Riv. Ital. Sostanze Grasse 79, 391-394.

Gunstone FD. 2000. Oils and fats in Europe. Eur. J. Lipid Sci. Technol. 102, 1-2. 
Gunstone FD. 2001. Production and consumption of rapeseed oil on a global scale. Eur. J. Lipid Sci. Technol. 103, 447-449.

Kowalski B., Gruczynska E., Tarnowska K., Bekas W., Brys J. 2004a. Chemical interesterification of beef tallow and rapeseed oil blend in hydrocarbon solvent. Riv. Ital. Sostanze Grasse 81, 164-171.

Kowalski B., Gruczynska E., Maciaszek K. 2000. Kinetics of rapeseed oil oxidation by pressure differential scanning calorimetry measurements. Eur. J. Lipid Sci. Technol 102, 337-341.

Kowalski B., Ratusz K., Kowalska D., Bekas W. 2004b. Determination of the oxidative stability of vegetable oils by Differential Scanning Calorimetry and Rancimat measurements. Eur. J. Lipid Sci. Technol. 106, 165-169.

Ledochowska E., Wilczynska E. 1998. Comparison of the oxidative stability of chemically and enzymatically interesterified fats. Fett/Lipid 100, 343-348.

Ledochowska E., Datta I. 1998. Optimization of enzymatic interesterifications of fats to increase the content of triacylglycerols in the reaction product. Polish J. Food and Nutrition Sciences 7/48, 683-691.
Lo YC., Handel AP. 1983. Physical and chemical properties of randomly interesterified blends of soybean oil and tallow for use as margarine oils. J. Am. Oil Chem. Soc. 60, 815-818.

Mohamed HMA., Bloomer S., Hammadi K. 1993. Modification of fats by lipase interesterification: Changes in glyceride structure. Fat Sci. Technol. 11, 428-431.

Rodríguez A., Castro E., Salinas MC., López R., Miranda M., Rosales VP. 2001. Interesterification of tallow and sunflower oil. J. Am. Oil Chem. Soc. 78, 431-436.

$\mathrm{Xu}$ X., Skands ARH., Hoy CE., Mu H., Balchen S., Adler-Nissen J. 1998. Production of specific structured lipids by enzymatic interesterification: elucidation of acyl-migration by response surface design. J. Am. Oil Chem. Soc. 75, 1179-1186. 